\title{
Classification and Subject Headings
}

compiled by Anna Appleman

Johnson, Mackenzie and Carlie Forsythe. 2019. "Disability and Accessibility Language in Subject Headings and Social Tags.” Catalogue and Index 197 (December): 16-26.

Lo, Grace. 2019. “'Aliens’ vs. Catalogers: Bias in the Library of Congress Subject Heading.” Legal Reference Services Quarterly 38, no. 4 (October): 170-96.

Laddusaw, Sierra. 2019. "Classifying the Imaginary: An Expansion of Library of Congress' Subclass G9930 for Local Use.” Cataloging \& Classification Quarterly 57, no. 4 (May): 197-205.

Masterson, Maeva, Carol Stableford, and Anja Tait. 2019. "Re-Imagining Classification Systems in Remote Libraries.” Journal of the Australian Library \& Information Association 68, no. 3 (September): 278-89.

Saarti, Jarmo. 2019. "Fictional Literature, Classification and Indexing.” Knowledge Organization 46, no. 4 (June): 320-32. 